\title{
BID-dependent and BID-independent pathways for BAX insertion into mitochondria
}

\author{
SC Ruffolo ${ }^{1}$, DG Breckenridge ${ }^{1}, M_{\text {Nguyen }}{ }^{1}$, IS Goping', \\ A Gross ${ }^{2}$, SJ Korsmeyer ${ }^{2}, \mathrm{H} \mathrm{Li}^{3}$, J Yuan ${ }^{3}$ and GC Shore ${ }^{\star, 1}$ \\ 1 Department of Biochemistry, McIntyre Medical Sciences Building, McGill \\ University, Montreal, Quebec, Canada H3G 1Y6 \\ 2 Department of Cancer Immunology and Aids, Dana-Farber Cancer Institute, \\ Harvard Medical School, Boston, MA 02115, USA \\ ${ }^{3}$ Department of Cell Biology, Harvard Medical School, Boston, MA 02115, USA \\ * Corresponding author: GC Shore, Department of Biochemistry, McIntyre \\ Medical Sciences Building, McGill University, Montreal, Quebec, Canada H3G \\ $1 Y 6$ \\ Tel: (514) 398-7282; Fax: (514) 398-7384; \\ E-mail: shore@med.mcgill.ca
}

Received 28.2.00; revised 8.6.00; accepted 4.7.00

Edited by JM Hardwick

\begin{abstract}
In the absence of an apoptotic signal, BAX adopts a conformation that constrains the protein from integrating into mitochondrial membranes. Here, we show that caspases, including caspase-8, can initiate BAX insertion into mitochondria in vivo and in vitro. The cleavage product of caspase-8, tBID, induced insertion of BAX into mitochondria in vivo, and reconstitution in vitro showed that $t B I D$, either directly or indirectly, relieved inhibition of the BAX transmembrane signal-anchor by the $\mathrm{NH}_{2}$-terminal domain, resulting in integration of BAX into mitochondrial membrane. In contrast to these findings, however, Bid-null mouse embryo fibroblasts supported Bax insertion into mitochondria in response to death signaling by either TNF $\alpha$ or E1A, despite the fact that cytochrome $c$ release from the organelle was inhibited. We conclude, therefore, that a parallel Bid-independent pathway exists in these cells for mitochondrial insertion of Bax and that, in the absence of Bid, cytochrome $c$ release can be uncoupled from Bax membrane insertion. Cell Death and Differentiation (2000) 7, 1101-1108.
\end{abstract}

Keywords: apoptosis; BAX; BID; mitochondria; Fas; TNF; E1A

Abbreviations: ART, apoptotic regulation of BAX targeting

\section{Introduction}

Induction of apoptotic pathways in response to death signals is critically dependent on the status of survival/death regulators within a cell. Prominent among these is the BCL2 family of anti-apoptotic (BCL-2, BCL- $\mathrm{X}_{\mathrm{L}}, \mathrm{BCL}-\mathrm{w}, \mathrm{MCL}-1, \mathrm{~A}-$ 1) and pro-apoptotic (BAX, BAK, BOK) members, whose activities and ability to form heterodimers is influenced by a third subgroup of the BCL-2 family, which includes mammalian BID, BAD, BIK, BIM, BLK, HRK, and C. elegans
EGL-1. ${ }^{1,2}$ The latter are proapoptotic and contain a minimal apoptotic domain, $\mathrm{BH} 3$, which targets these proteins for interaction with BCL-2 proteins. Several of these ' $\mathrm{BH} 3$ domain only' members, including BID, BAD, and BIM, are themselves influenced by specific signal transduction pathways, ${ }^{3-7}$ which serve to link the BCL-2.BAX checkpoint to upstream celldeath initiating events. BCL-2 and BAX each contain a single transmembrane segment at their extreme $\mathrm{COOH}$-terminus, which is responsible for targeting these proteins into membrane sites, including mitochondria, ${ }^{8-10}$ where their opposing functions influence organellar integrity and function. ${ }^{11}$ In situations where anti-apoptotic BCL-2 members are limiting, mitochondria undergo profound dysfunction in response to most death signals. This includes release of cytochrome $c$ from the intermembrane space, ${ }^{12,13}$ which triggers activation of downstream caspases,${ }^{14}$ and ultimately induction of permeability transition at the inner membrane, resulting in loss of the electrochemical potential and production of excess reactive oxygen species. ${ }^{11}$ Recently, mitochondrial transformations have been directly linked to cleavage of cytosolic BID by caspases, including caspase-8, in the CD95/Fas and TNFR1 cell death pathways, at least in certain cell types in culture. The resulting product, tBID, targets the organelle and induces cytochrome $c$ release. ${ }^{4-6}$ This signaling event in the Fas/TNFR1 pathway is likely an important contribution to apoptosis only in type II cells in culture, where upstream induction of the pathway following receptor-mediated activation of caspase-8 may be amplified via mitochondrial transformations. ${ }^{15}$ Further, such amplification by mitochondria may involve additional factors that operate in parallel to BID. ${ }^{16}$

$B A X$, like BID, is constrained from targeting membrane sites, including mitochondria, until the cell receives a death signal. ${ }^{9,17,18}$ In the absence of such a signal, BAX adopts a conformation in which the $\mathrm{COOH}$-terminal transmembrane signal-anchor domain of BAX cannot insert into membranes, and this is dependent at least in part on the $\mathrm{NH}_{2}-$ terminal ART (Apoptotic Regulation of Targeting) domain. This repression by ART is relieved by a death stimulus and the signal-anchor now inserts BAX into mitochondrial membrane. ${ }^{9}$ Membrane insertion is accompanied by a conformational change in the protein, in which the $\mathrm{NH}_{2}$ terminus of BAX now becomes exposed. ${ }^{19}$ Alternatively, BAX translocation can be uncoupled from death signals by forced overexpression ${ }^{18,20,21}$ or forced dimerization..$^{18}$ Such induced translocation of BAX results in mitochondrial permeability transition ${ }^{18,22}$ and in some contexts causes cytochrome $c$ release. ${ }^{21,23}$ Moreover, BID and BAX can interact $^{19,24}$ and both molecules can induce loss of mitochondrial integrity by mechanisms inhibited by BCL-2 proteins. ${ }^{4,5,18,19,25,26}$

Here, we have studied the mechanism that stimulates BAX insertion into mitochondria following a death signal. We demonstrate that caspase-generated p15 tBID, either 
directly or indirectly, releases inhibition of the $\mathrm{COOH}$ terminal signal anchor of $\mathrm{BAX}$ by the $\mathrm{NH}_{2}$-terminal ART domain, and mediates BAX membrane integration. In certain cell types, however, parallel pathway(s) exist to achieve the same end.

\section{Results}

Activation of Fas causes recruitment of initiator procaspase-8 into the death-inducing signaling complex (DISC) via the adaptor molecule FADD. ${ }^{27-29}$ This stimulates autoactivation of procaspase- $8^{29,30}$ which then initiates an apoptotic pathway that, in type II cells in culture, involves a mitochondrialdependent amplification of caspase activation. ${ }^{15,31}$ Recent genetic analysis ${ }^{32,33}$ has revealed that caspase- 8 is an obligate and non-redundant constituent at the apex of this pathway. In Figure 1A, type II human KB epithelial cells were mock-treated or treated with agonistic anti-Fas antibody in the presence of cycloheximide, ${ }^{34}$ and BAX in whole cell lysate or in a heavy membrane fraction enriched in mitochondria ${ }^{9}$ was detected by immunoblotting. Activation of Fas resulted in neither an increase in levels of total cellular BAX (cell lysate) nor in the amount of $\mathrm{BAX}$ recovered with mitochondria. Extraction of these mitochondria with $0.1 \mathrm{Na}_{2} \mathrm{CO}_{3}, \mathrm{pH} 11.5$, however, which liberates proteins that are peripherally associated with the surface of membranes but retains proteins that are integrated into the lipid bilayer, ${ }^{35}$ revealed significant differences. Whereas TOM20, a protein import receptor constitutively integrated into the lipid bilayer of the outer membrane by a single transmembrane domain, ${ }^{36}$ was equally resistant to alkaline extraction in mitochondria obtained from cells with or without Fas stimulation, BAX resisted alkaline extraction only in mitochondria from Fasstimulated cells. Membrane integration of BAX was abolished, however, when Fas-stimulation was conducted in the presence of the wide-spectrum caspase inhibitor, zVADfmk. We conclude, therefore, that upstream caspase- 8 in the Fas pathway can initiate a caspase-dependent pathway for BAX integration into mitochondrial membrane. Furthermore, murine tBid, which is generated by cleavage of p22 Bid by caspase-8 in the Fas pathway, also stimulated BAX integration into mitochondrial membrane when expressed ectopically in human $\mathrm{H} 1299$ epithelial cells in the absence of Fas stimulation, whereas a BH3-defective mutant of tBid, in which leu at position 90 within helix 3 was replaced with gly, did not (Figure 1B).

\section{Reconstitution of caspase-dependent insertion of BAX into mitochondria in vitro}

Consistent with the findings from Fas-stimulated KB cells, treatment of a control cytosol fraction from human HeLa epithelial cells ${ }^{9}$ with caspase-8 induced the endogenous BAX in this fraction, when combined with purified rat heart mitochondria, to acquire resistance to alkali extraction, as assessed by immunoblotting (Figure 2B, lanes 1 and 2). Heart mitochondria were employed for these analyses because they can be isolated intact and contain negligible amounts of associated Bax, as determined by immunoblotting (not shown). As well, the treated extracts were capable of subsequently cleaving exogenous PARP (not shown), indicating that caspases were in fact active. A similar amount of alkali-resistant BAX was observed upon dATP-activation of the endogenous caspases in HeLa extract at $37^{\circ} \mathrm{C},{ }^{9,37}$ followed by incubation of the extract with mitochondria in the presence of the pan caspase inhibitor, zVAD-fmk (lane 5). In contrast, if zVAD-fmk was added to the extract prior to activation of endogenous caspases with dATP, BAX insertion into mitochondria was ablated (lane 4). Therefore, caspase(s) induce BAX membrane insertion by acting on a pre-existing constituent in the HeLa cell extract. Similar results were obtained for the influence of the zVAD-treated HeLa cell extract on membrane insertion of the ${ }^{35} \mathrm{~S}$-labeled, full-length BAX translation product (Figure 2A). Again, ZVAD was

A

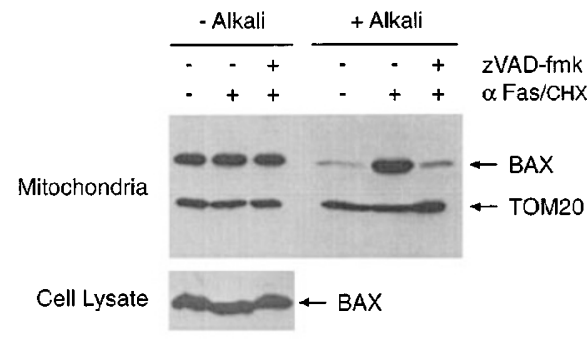

B

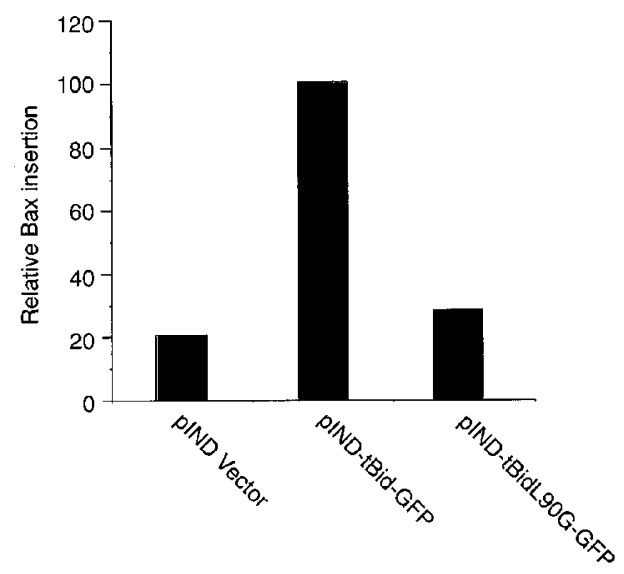

Figure 1 Induction of BAX insertion into mitochondrial membrane in human epithelial cells following stimulation of Fas or expression of murine tBid. (A) Human KB epithelial cells were mock-treated or treated with $0.5 \mu \mathrm{g} / \mathrm{ml}$ mouse monoclonal anti-human Fas (Upstate Biotechnology) and $10 \mu \mathrm{g} / \mathrm{ml}$ cycloheximide $(\mathrm{CHX})^{34}$ in the presence or absence of $50 \mu \mathrm{M}$ zVAD-fmk for $14 \mathrm{~h}$. Cells were homogenized and heavy membranes enriched in mitochondria recovered from the cell lysates, ${ }^{9}$ subjected to SDS-PAGE either directly (-Alkali) or after extraction with $0.1 \mathrm{M} \mathrm{Na}_{2} \mathrm{CO}_{3}$ (+Alkali) (from twice the mitochondria as -Alkali), ${ }^{9}$ and immunoblots developed with rabbit anti-BAX N-20 antibody (Santa Cruz Biotechnology, Santa Cruz, CA, USA) and chicken anti-TOM20 and visualized by enhanced chemiluminescence. (B) Human H1299 epithelial cells were transfected with control vector, pIND-tBid-GFP, or pINDtBid(L90G)-GFP and after $24 \mathrm{~h}$, expression was induced with $5 \mu \mathrm{M}$ ponasterone. ${ }^{5}$ After $4 \mathrm{~h}$, cells were recovered and the alkali-insoluble mitochondrial protein was analyzed by immunoblotting as in $(\mathbf{A})$, and the bands quantified using a Power Macintosh 7200/120 and NIH Image v.1.61 image analysis software. BAX expression was normalized by dividing the BAX signal by the TOM20 signal, and setting the maximum value to 100 

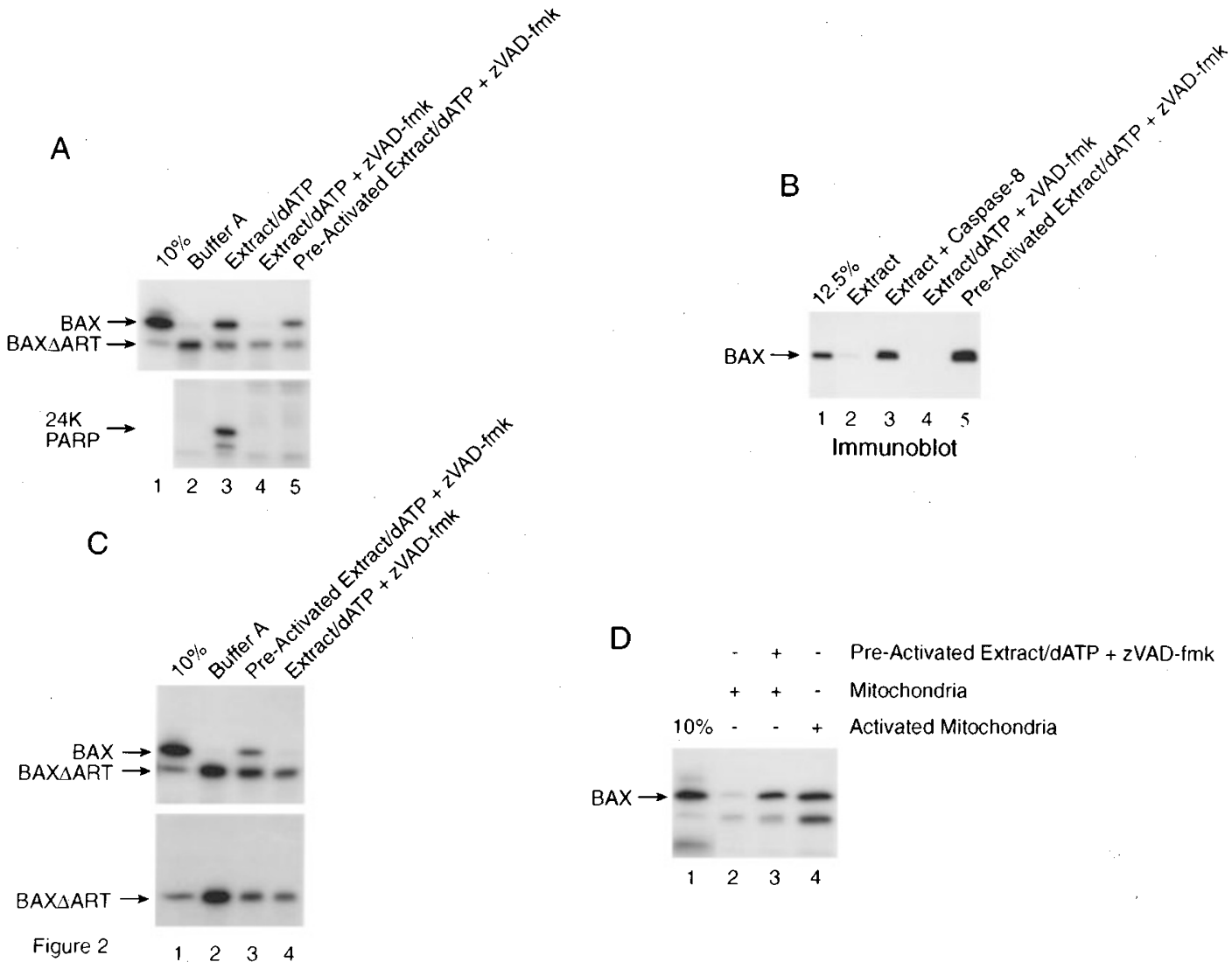

D $\quad+\quad+$ Pre-Activated Extract/dATP + zVAD-fmk

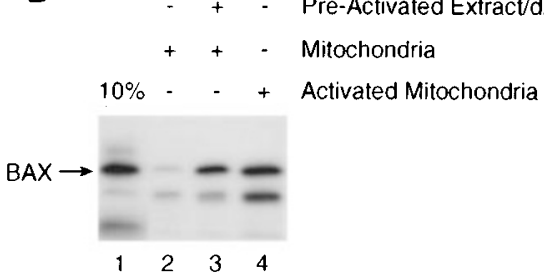

$\begin{array}{lllll}\text { Figure } 2 & 1 & 2 & 3 & 4\end{array}$

Figure 2 Caspase-dependent insertion of BAX into mitochondrial membrane in HeLa cell extracts requires a cytosolic factor(s). (A) Influence of caspase activation on BAX membrane insertion and PARP cleavage. Upper panel, $\left[{ }^{35} \mathrm{~S}\right] \mathrm{BAX}$ and $\left[{ }^{35} \mathrm{~S}\right] \mathrm{BAX} \triangle \mathrm{ART}$ translation products were incubated with isolated rat heart mitochondria for $60 \mathrm{~min}$ at $37^{\circ} \mathrm{C}$ under standard protein import conditions ${ }^{9}$ in the presence of buffer (lane 2); extract/dATP, in which the caspases in the HeLa extract had been activated by dATP (lane 3); extract/dATP plus zVAD-fmk, in which the zVAD-fmk was added prior to caspase activation by dATP (lane 4); and preactivated extract/dATP plus zVAD-fmk, in which the zVAD-fmk was added after activation of the caspases by dATP (lane 5). The mitochondria were subsequently collected, extracted with $0.1 \mathrm{M} \mathrm{Na}_{2} \mathrm{CO}_{3}, \mathrm{pH} 11.5,{ }^{9}$ and the integral membrane proteins analyzed by SDS-PAGE and fluorography. ${ }^{9}$ Lane 1 represents $10 \%$ of input $\left[{ }^{35} \mathrm{~S}\right] \mathrm{BAX}$. Lower panel, extracts were incubated as above in the absence of mitochondria and subsequently added to [ $\left.{ }^{35} \mathrm{~S}\right] \mathrm{PARP}$ translation product for $60 \mathrm{~min}$ at $30^{\circ} \mathrm{C}$ (lanes $2-5$ ) and the $24 \mathrm{kDa}$ apoptotic cleavage product of PARP detected by SDS-PAGE and fluorography. ${ }^{9}$ (B) Influence of exogenous caspase8. Purified mitochondria were incubated with untreated HeLa extract (lane 2); untreated extract plus $4 \mathrm{ng} / \mu \mathrm{l}$ caspase-8 (Pharmingen) (lane 3 ); extract/dATP plus ZVAD-fmk (lane 4); and pre-activated extract/dATP plus zVAD-fmk (lane 5). The mitochondria were subsequently treated as in (A). Insertion of endogenous BAX in the extract was determined by immunoblotting with rabbit anti-BAX N-20 antibody (Santa Cruz), followed by enhanced chemiluminescence. Lane 1 , BAX in $12.5 \%$ of the input HeLa extract. (C) Deletion of the BAX ART domain. As in (A) except that $\left[{ }^{35} \mathrm{~S}\right] \mathrm{BAX}$ and $\left[{ }^{35} \mathrm{~S}\right] \mathrm{BAX} \triangle \mathrm{ART}$ (upper panel) or [ $\left.{ }^{35} \mathrm{~S}\right] \mathrm{BAX} \Delta \mathrm{ART}$ (lower panel) translation products were incubated with mitochondria in the presence of buffer (lane 2); pre-activated extract/dATP plus zVAD-fmk (lane 3); and extract/dATP plus ZVAD-fmk (lane 4). Lane 1, 10\% of input translation product. (D) As in (A) except that $\left[{ }^{35} \mathrm{~S}\right] \mathrm{BAX}$ translation product was incubated with mitochondria in the presence of buffer (lane 2); pre-activated extract/dATP plus zVAD-fmk (lane 3); or the mitochondria were treated with pre-activated extract/dATP plus zVAD-fmk and the mitochondria re-isolated by centrifugation and resuspended and incubated for $60 \mathrm{~min}$ in the presence of buffer alone and [ $\left.{ }^{35} \mathrm{~S}\right] \mathrm{BAX}$ (lane 4 )

inhibitory when added prior to dATP-dependent activation of extract caspases at $37^{\circ} \mathrm{C}$ (lane 4 ) but not when added after caspase activation (lane 5 ). In contrast, generation of the apoptotic $24 \mathrm{kDa}$ caspase cleavage product of PARP was inhibited by zVAD-fmk in either circumstance (lanes 4 and 5). Of note, deletion of the $\mathrm{NH}_{2}$-terminal 19 amino acid ART domain from $B A X^{9}$ allowed $\left[{ }^{35} \mathrm{~S}\right] \mathrm{BAX} \triangle \mathrm{ART}$ to bypass the requirement for the caspase-activated factor, and this was true if the BAX $\triangle A R T$ translation product was presented to mitochondria either alone (Figure $2 \mathrm{C}$ ) or together with full length BAX (Figure 2A,C).

Molecular seive chromatography indicated that most of the $\left[{ }^{35} \mathrm{~S}\right] \mathrm{BAX}$ translation product existed as a monomer (data not shown), consistent with the observations in vivo for the cytosolic form of the protein. ${ }^{17,18}$ Incubation of this translation product with activated HeLa extract did not result in either cleavage of BAX or induction of a higher order structure. Though not conclusive, this suggests that the cytosolic factor influences BAX targeting either indirectly or at the level of the mitochondrion. Consistent with the latter, incubation of mitochondria with activated extract, followed by their re-isolation and subsequent incubation of these activated mitochondria in a standard BAX import reaction, in the absence of HeLa extract, revealed BAX insertion into mitochondrial membrane to a similar extent as for BAX import conducted with control mitochondria in the continued presence of activated extract (Figure 2D, lanes 3 and 4). This suggests that the caspase-regulated factor either associates with mitochondria or modifies a constituent of the organelle requisite for BAX membrane insertion, or both. 


\section{The caspase-regulated factor is BID}

Partial purification of the caspase regulated factor in HeLa cell extracts revealed a BAX mitochondrial-insertion stimulating activity associated with $\mathrm{a} \sim 15 \mathrm{kDa}$ protein (data not shown). BID's $\mathrm{NH}_{2}$-terminal domain is removed by caspases, including caspase-8, to yield p15 tBID, which then targets mitochondria and induces mitochondrial dysfunction. ${ }^{4-6}$ When BID was removed from HeLa cell extract by immunodepletion with antibody against BID prior to activation of caspases (Figure $3 A$, right panel lane 3), the ability of the endogenous $B A X$ in these extracts to insert into mitochondrial membrane was lost upon subsequent caspase activation (left panel, lane 3). Addition of recombinant BID to these BIDdepleted extracts reinstated BAX membrane insertion following activation of endogenous caspases (left panel, lane 4). Moreover, direct addition of low concentrations $(12 \mathrm{nM})$ of recombinant tBID, generated by caspase-8 cleavage of full length $\mathrm{BID},{ }^{5}$ to in vitro translated $\left[{ }^{35} \mathrm{~S}\right] \mathrm{BAX}$ could replace the requirement for activated extract and on its own stimulated $\left[{ }^{35} \mathrm{~S}\right] \mathrm{BAX}$ insertion into mitochondrial membrane (Figure $3 B$, lane 8). Full length BID was also

A

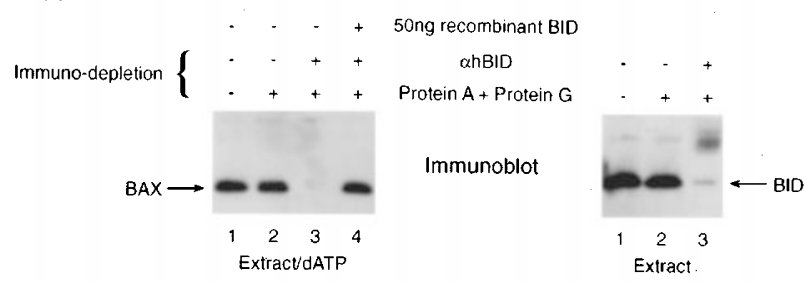

B

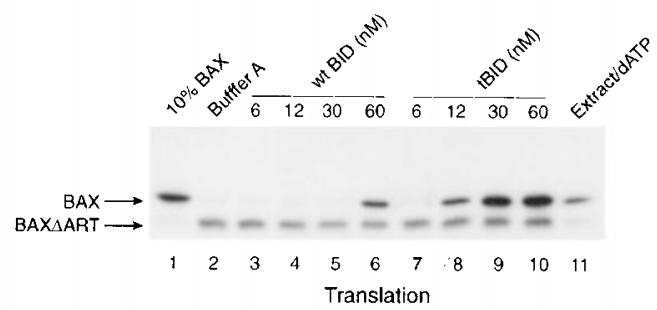

Figure 3 BID is required for caspase-dependent insertion of BAX into mitochondrial membrane in HeLa cell extracts. (A) Influence on endogenous BAX. Right panel. Untreated HeLa extract was incubated with Proteins A and $G$ Sepharose in the presence (lane 3) or absence (lane 2) of rat anti-BID antibody, and immune complexes removed by centrifugation. Subsequently, a fraction of the immunodepleted extracts (lanes 2 and 3 ) and untreated extract (lane 1) were immunoblotted with the same anti-BID antibody and visualized by enhanced chemiluminescence. Left panel. Each of the extracts above were then activated by adding dATP. Rat heart mitochondria were subsequently incubated with extract/dATP (lane 1); mock immunodepleted extract/dATP (minus antibody) (lane 2); BID-immunodepleted extract/dATP (lane 3); and BID-immunodepleted extract/dATP with $50 \mathrm{ng}$ of recombinant BID $^{5}$ added to it (lane 4). The mitochondria were then collected, extracted with $0.1 \mathrm{M} \mathrm{Na}_{2} \mathrm{CO}_{3}$, $\mathrm{pH} 11.5$, and the insoluble protein analyzed by immunoblotting with rabbit antiBAX N-20 antibody. (B) Translation products. $\left[{ }^{35} \mathrm{~S}\right] \mathrm{BAX}$ and $\left[{ }^{35} \mathrm{~S}\right] \mathrm{BAX} \triangle \mathrm{ART}$ translation products were incubated with mitochondria under standard protein import conditions ${ }^{9}$ in the presence of buffer (lane 2); the indicated concentrations of either full length BID (lanes 3-6) or p15 tBID, which had been generated by cleavage of BID with caspase-8 (lanes $7-10)^{5}$; or extract/ dATP (lane 11). The mitochondria were subsequently collected and analyzed as in Figure $2 \mathrm{~A}$ stimulatory, but only at higher concentrations (lane 6). Likewise, full length BID can stimulate release of cytochrome $c$ from mitochondria, but at concentrations higher than that of p15 tBID. ${ }^{4-6}$ Consistent with the results using cell extracts (Figure 2A,C), however, membrane insertion of $\left[{ }^{35}\right.$ S]BAX $\triangle A R T$ did not depend on and was not further stimulated by either BID or $\mathrm{B} B \mathrm{D}$, even at high concentrations of tBID (Figure 3B).

\section{Effect of Bid gene deletion in mouse embryo fibroblasts}

Previous analysis of embryonic fibroblasts from the $\mathrm{Bid}^{-1-}$ mouse revealed only a slight delay in cell killing in response to $\mathrm{TNF} \alpha$ compared to $\mathrm{Bid}^{+/+}$cells, yet a significant inhibition of cytochrome $c$ release from mitochondria in the Bid-null cells was observed. ${ }^{38}$ Similarly, $\mathrm{Bid}^{-1-}$ mouse embryo fibroblasts were delayed in cell killing following expression of $E 1 A$ oncoprotein (Figure 4A) yet, again, there was an inhibition of cytochrome $c$ release from mitochondria as assessed by confocal microscopy, although the organelle did assume a condensed morphology as a consequence of E1A expression (Figure 4B). Analysis of the high-speed supernatant fraction from E1A-stimulated cells by immunoblotting likewise showed an inhibition of cytochrome $c$ release to the cytosol in $\mathrm{Bid}^{-1-}$ cells (Figure 4C). Of note, however, E1A expression resulted in Bax insertion into mitochondrial membrane to a similar extent in $\mathrm{Bid}^{-1-}$ and $\mathrm{Bid}^{+/+}$cells over the time course examined (Figure 4D). This lack of difference between the two cell types was evident even though E1A stimulated Bid cleavage in the wild-type cells (Figure 4A, inset). Likewise, TNF $\alpha$ treatment stimulated Bax insertion into mitochondrial membrane to the same extent in $\mathrm{Bid}^{-1-}$ and $\mathrm{Bid}^{+/+}$cells. Thus, in both cases cell death and Bax insertion into mitochondria can bypass the requirement for Bid in this murine cell type.

\section{Discussion}

Under normal physiological conditions, BAX membrane insertion is regulated and tied to specific signal transduction events. ${ }^{9,17,18}$ In the absence of death signals, BAX adopts a conformation in which the $\mathrm{COOH}$-terminal transmembranesignal anchor is repressed and incapable of targeting the protein to mitochondria. ${ }^{9,10}$ We show here that activation of caspases, both in vivo and in vitro, can over-ride this inhibition and BAX now inserts into mitochondrial membrane. This contribution by caspases may reflect an initiation and/or amplification of regulated BAX targeting. Further, we find that caspase-generated tBID is a direct stimulus of BAX insertion into mitochondrial membrane in vitro and can initiate $B A X$ membrane insertion in vivo in the absence of other death signals. This dependence of BAX membrane insertion on tBID was bypassed, however, by deleting the BAX $\mathrm{NH}_{2}$ ART domain. Deletion of the ART domain also enhanced the toxicity of BAX in transfected cells. ${ }^{9}$ Therefore, at least in certain contexts, caspase-generated tBID is an upstream stimulus of BAX targeting that, directly or indirectly, can relieve repression of the $\mathrm{COOH}$-terminal $\mathrm{BAX}$ transmembrane signal-anchor segment by the $\mathrm{NH}_{2}$-terminal ART 
A

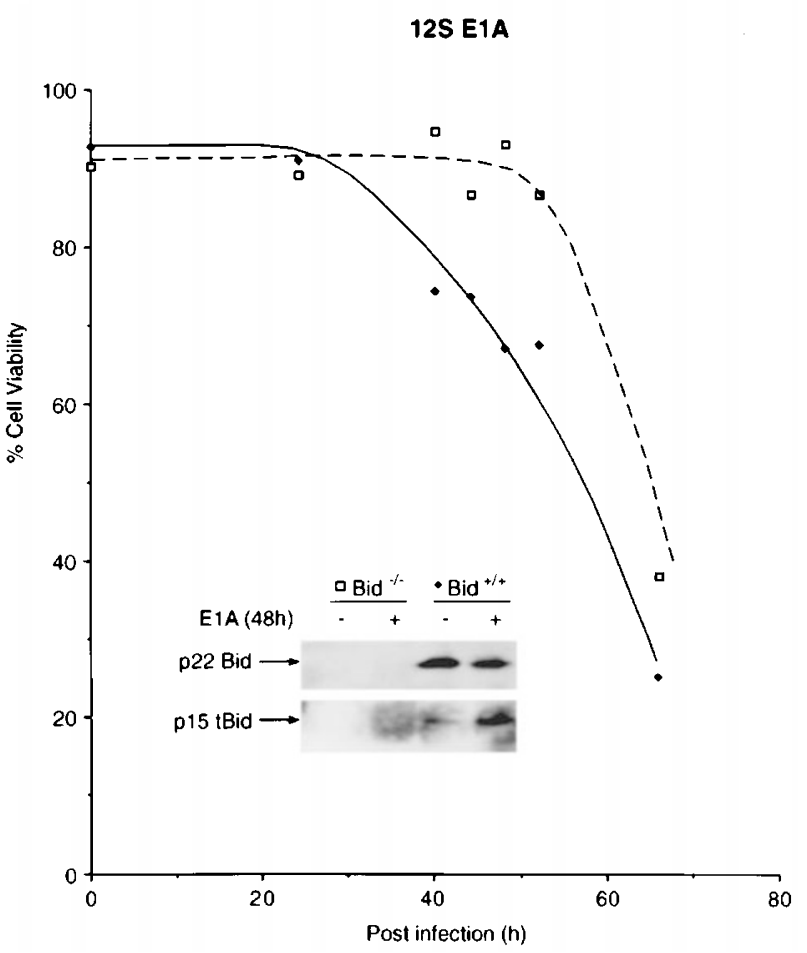

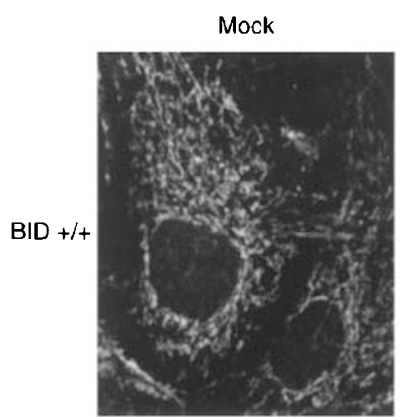
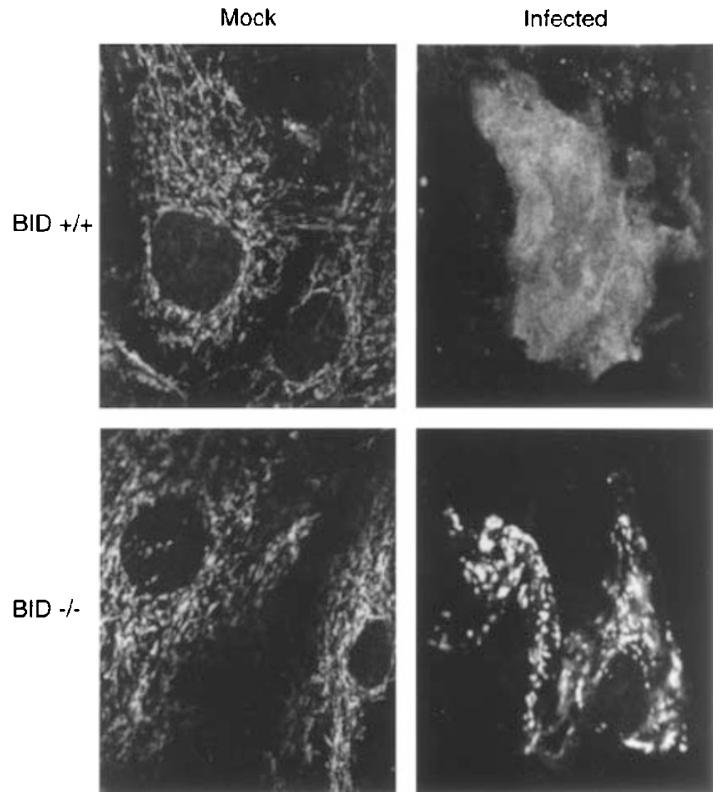

C
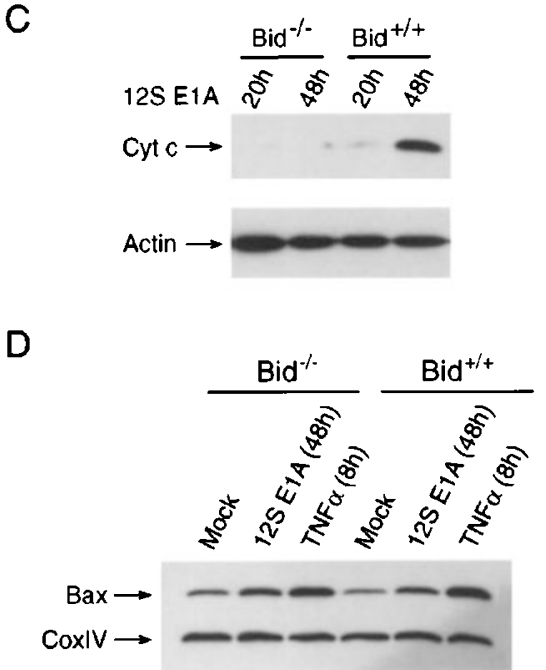

Figure $4 \mathrm{Bid}^{+/+}$and $\mathrm{Bid}^{-1-}$ mouse embryo fibroblasts. (A) Influence on cell killing by E1A. Primary embryo fibroblasts from $\mathrm{Bid}^{+/+}$and $\mathrm{Bid}^{-1-} \mathrm{mice}^{38}$ were infected for the indicated times with adenovirus type 5 dl53OE1B- (expressing only $12 \mathrm{SE} 1 \mathrm{~A}$ and no E1B products) ${ }^{45}$ Cell viability was measured by exclusion of trypan blue. The data are an average of two independent determinations and are representative of multiple killing curves by E1A. After $48 \mathrm{~h}$, infected $(+)$ and mockinfected (-) cells were analyzed by immunoblotting with anti-mouse Bid (inset; the lower panel showing tBid was developed by chemiluminescence for twice as long as in the upper panel). (B) Influence of E1A expression on cytochrome $c$ distribution. As in A except that cells, infected with or without dl52OE1B ${ }^{-}$, were grown on glass cover slips for $48 \mathrm{~h}$, fixed, and incubated with mouse monoclonal antibody 2G8.B6 against cytochrome $c$ and anti-mouse lgG coupled to Texas Red, and visualized by immunofluorescence confocal microscopy. Representative images are shown. (C) As in (A) except that cells were infected for 20 or $48 \mathrm{~h}$ with adenovirus type 5 dl52OE1B- (expressing only $12 \mathrm{~S} \mathrm{E1A}$ and no E1B products), and high-speed supernatant fractions were generated and analyzed by immunoblotting for cytochrome $c$ and actin. (D) As in (A) except that cells infected with adenovirus type 5 dl52OE1B $\mathrm{B}^{-}$for $48 \mathrm{~h}$ or with TNF $\alpha$ for $8 \mathrm{~h}^{38}$ were homogenized and the heavy membrane fraction containing mitochondria was recovered and extracted with $0.1 \mathrm{M} \mathrm{Na}_{2} \mathrm{CO}_{3}, \mathrm{pH} 11.5 .^{9}$ The insoluble protein was subjected to SDS - PAGE and developed by immunoblotting with rabbit anti-BAX N-20 antibody (Santa Cruz Biotechnology, Santa Cruz, CA, USA) and mouse anticytochrome $c$ oxidase subunit IV (Cox IV) antibody ${ }^{9}$

domain, ${ }^{9}$ permitting $\mathrm{BAX}$ integration into mitochondrial membrane (Figure 5). A number of point mutations within different regions in $\mathrm{BAX}$, including the $\mathrm{NH}_{2}$-terminal ${ }^{39}$ and
$\mathrm{COOH}$-terminal domains, ${ }^{10}$ and the putative pore-forming helices 5 and $6,{ }^{40}$ can also bypass the requirement for such regulation and permit constitutive targeting of $B A X$ to 


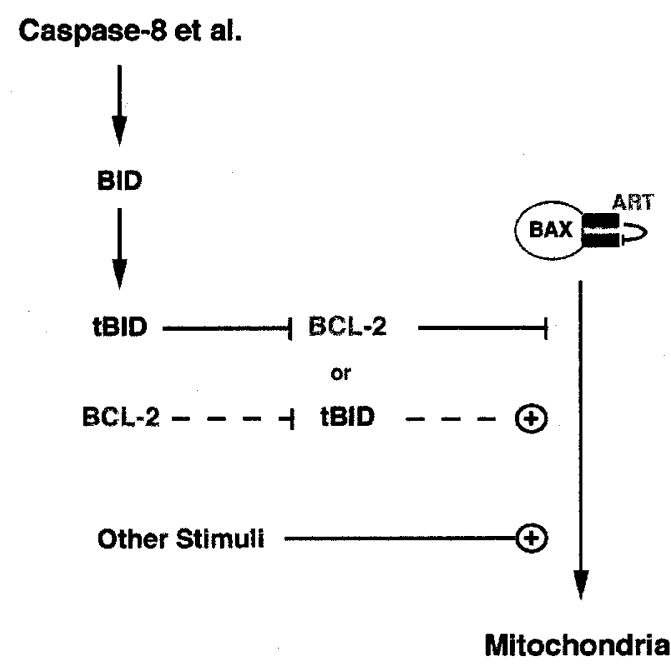

Figure 5 Working model for regulation of $\mathrm{BAX}$ insertion into mitochondria by BID. See the text for a description. The $\mathrm{NH}_{2}$-terminal ART and $\mathrm{COOH}$-terminal transmembrane domains of BAX are represented by upper and lower boxes, respectively

mitochondria, as can exposure of the wild-type protein to elevated $\mathrm{pH}^{39}$ As well, it will be interesting to learn if other $\mathrm{BH} 3$ domain-only proteins, such as BAD and BIM, can act like tBID and induce BAX targeting. It may be that the 'closed' inactive conformation of BAX, which correlates with inaccessibility of the $\mathrm{NH}_{2}$-terminal domain to added protease, ${ }^{9,19}$ can be perturbed or accessed by a variety of both intrinsic and extrinsic factors in addition to tBID, a situation that presumably accounts for the ability of $\mathrm{Bid}^{-1-}$ mouse embryo fibroblasts to support Bax membrane insertion in response to different death signals. Additionally, however, our findings revealed that, in the absence of Bid, insertion of Bax into mitochondria did not result in release of cytochrome $c$ from the organelle, indicating that the well-documented ability of Bax to stimulate cytochrome $c$ release may depend on cooperation with Bid in vivo.

The role of BID and other potential regulators in controlling BAX targeting to mitochondria must be interpreted in the context of two conditions that enable BAX to bypass such regulation in vivo. Forced overexpression $^{20-22}$ and forced dimerization ${ }^{18}$ of $\mathrm{BAX}$ both result in constitutive mitochondrial integration and cell death. ${ }^{1}$ Overexpression might saturate an inhibitory pathway of BAX membrane integration, a role that has been ascribed to anti-apoptotic BCL-2/BCL- $X_{L}$ family members. ${ }^{18}$ In this context, tBID might inactivate the BCL-2 death suppressors ${ }^{4-6}$ (Figure 5). Likewise, forced dimerization might preclude the influence of BCL-2 suppressors on BAX distribution, or cause a conformational change in $\mathrm{BAX}$ that bypasses regulation of its targeting to mitochondria.

A second possibility is that tBID takes a more direct role in $\mathrm{BAX}$ integration into mitochondria. ${ }^{19,41}$ For example, it may act as a receptor for BAX, inducing a conformational change in BAX and subsequent mem- brane insertion (Figure 5). In this scenario, BCL-2-related suppressors, if in excess, may bind and inactivate tBID. This model is consistent with studies in vitro showing that recombinant full-length BID can interact directly with $B A X$ and support both BAX insertion into mitochondria and subsequent release of cytochrome $c$ from the organelle. ${ }^{19,41}$ It is not clear, however, how this model reconciles with manipulations to $B A X$ (e.g., over-expression) that allows BAX to bypass the requirement for tBID as receptor or, conversely, with Bax membrane insertion being observed in stimulated Bid-null mouse embryo fibroblasts.

Finally, integration of tBID into mitochondria might exert influences beyond the regulation of other BCL-2 family members. For example, ion channel activity of tBID has been detected in vitro. ${ }^{42}$ Also, the involvement of regulators in the endoplasmic reticulum that influence BAX activity has been recorded. ${ }^{43}$ Further insights into the role of tBID in regulating $\mathrm{BAX}$ membrane insertion will undoubtedly emerge by elucidating the structural basis for this influence by tBID and by assessing the potential requirement for other factor(s) in this pathway.

\section{Materials and Methods}

\section{General}

Earlier studies describe the routine procedures for cell culture and infection with adenovirus type $5 \mathrm{~d} / 52 \mathrm{OE} 1 \mathrm{~B}^{-}$expressing only $12 \mathrm{~S} \mathrm{E} 1 \mathrm{~A}$ and no E1B products), ${ }^{44,45}$ and conducting immunocytochemistry by confocal microscopy, synthesizing $\left[{ }^{35} \mathrm{~S}\right] \mathrm{BAX}$ transcription-translation product in reticulocyte lysate, and isolating mitochondria from rat heart and cultured cells. ${ }^{9}$

\section{Insertion of BAX into mitochondrial membrane in vitro}

Apoptotic cell extracts were prepared from HeLa cells exactly as described by Goping et al. ${ }^{9}$ Twenty $\mu$ l of extract (approximately $10 \mathrm{mg}$ protein $/ \mathrm{ml}$ ), either alone or with $5 \mu \mathrm{l}$ of ${ }^{35} \mathrm{~S}$-methioninelabeled Bax transcription-translation product or $5 \mu \mathrm{l}$ of extract buffer, were incubated in a standard protein import reaction $(50 \mu \mathrm{l})$ containing purified mitochondria from rat heart $(1.0 \mathrm{mg}$ protein $/ \mathrm{ml}){ }^{9}$ Alternatively, the cell extraction buffer $(20 \mu \mathrm{l})$ alone replaced the extract in control reactions. The reaction mixtures were incubated for $60 \mathrm{~min}$ at $37^{\circ} \mathrm{C}$ in the absence of additives, or containing $1 \mathrm{mM}$ dATP (extract/dATP), or containing $1 \mathrm{mM}$ dATP and $50 \mu \mathrm{M}$ tetrapeptide zVAD-fmk added either at the beginning (extract/ $d A T P+z V A D-f m k$ ) or at the end (pre-activated extract/dATP+zVAD$\mathrm{fmk}$ ) of the incubation period. The mitochondria were recovered by centrifugation $^{9}$ and were analyzed by SDS-PAGE and fluorography to detect $\left[{ }^{35} \mathrm{~S}\right] \mathrm{Bax}$ or by immunoblotting with rabbit anti-BAX N2O antibody (Santa Cruz) to detect BAX derived from the HeLa cell extract. Analysis of rat heart mitochondria alone by immunoblotting revealed negligible Bax associated with the organelle. Alternatively, mitochondria isolated from reaction mixtures were resuspended $(0.25 \mathrm{mg}$ protein $/ \mathrm{ml})$ in freshly pre-

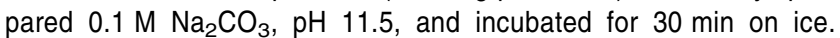
The membranes were then collected in an airfuge operating at 30 p.s.i. for $10 \mathrm{~min}$ prior to analysis by fluorography or immunoblotting. 


\section{Cytochrome $c$}

Cells $\left(4 \times 10^{6}\right)$ were washed in PBS and suspended in $0.1 \mathrm{ml} \mathrm{HIM}$ buffer (200 mM mannitol, $70 \mathrm{mM}$ sucrose, $1 \mathrm{mM}$ EDTA, $10 \mathrm{mM}$ HEPES, pH 7.5). After one cycle of freeze and thaw, the cells were homogenized with 25 strokes in a motorized Teflon-glass homogenizer operating at 500 r.p.m., and centrifuged at $800 \times g$ for $10 \mathrm{~min}$ to remove nuclei and cell debris. The supernatant was centrifuged at $100000 \times g$ for 10 min and aliquots from equivalent numbers of cells were subjected to SDS-PAGE and immunoblotting with mouse monoclonal $7 \mathrm{H} 8.2 \mathrm{C} 12$ anti-cytochrome $c$.

\section{Bid-null mouse embryo fibroblasts}

Mouse embryo fibroblasts were prepared from 9.5 day-old embryos of mice carrying a homozygous deletion in the coding region of Bid. ${ }^{38}$ They were cultured in Iscove's modified Dulbecco's medium containing $20 \%$ fetal calf serum, and infected with adenovirus type 5 dl52OE1B ${ }^{-}$(expressing only $12 \mathrm{~S} E 1 \mathrm{~A}$ and no $\mathrm{E} 1 \mathrm{~B}$ products) or treated with TNF $\alpha$, as described. ${ }^{38,46}$

\section{Acknowledgments}

This work was supported by operating grants from the Medical Research Council and National Cancer Institute of Canada. HeLa cells were obtained from the National Cell Culture Center, Minneapolis, Minnesota. SC Ruffolo was supported by fellowships from FCAR-FRSQ and MRC, and DG Breckenridge by the Max Stern Recruitment Fellowship from McGill University and MRC.

\section{References}

1. Gross A, McDonnell JM and Korsmeyer SJ (1999) Bcl-2 family members and the mitochondria in apoptosis. Genes Dev. 13: 1899-1911

2. Adams JM and Cory S (1998) The Bcl-2 protein family: arbiters of cell survival. Science 281: $1322-1326$

3. Zha J, Harada H, Yang E, Jockel J and Korsmeyer SJ (1996) Serine phosphorylation of death agonist Bad in response to survival factor results in binding to 14-3-3 not Bcl-X. Cell 87: 619-626

4. Luo X, Budihardji I, Zou H, Slaughter C and Wang X (1998) Bid, a Bcl2 interacting protein, mediates cytochrome $\mathrm{C}$ release from mitochondria in response to activation of cell surface death receptors. Cell 94: 481-490

5. LiH, Zhu H, Xu C-J and Yuan J (1998) Cleavage of Bid by caspase 8 mediates the mitochondrial damage in the Fas pathway of apoptosis. Cell 94: 491-501

6. Gross A, Yin X-M, Wang K, Wei MC, Jockel J, Milliman C, Erdjument-Bromage H, Tempst $P$ and Korsmeyer SJ (1999) Caspase cleaved Bid targets mitochondria and is required for cytochrome $\mathrm{c}$ release, while $\mathrm{Bcl}-\mathrm{X}_{\mathrm{L}}$ prevents this release but not tumor necrosis factor-R1/Fas Death. J. Biol. Chem. 274: 1156-1163

7. Puthalakath H, Huang DCS, O'Reilly LA, King SM and Strasser A (1999) The proapoptotic activity of the Bcl-2 family member Bim is regulated by interaction with the dynein motor complex. Mol. Cell 3: 287-296

8. Nguyen M, MillerDG, Yong VW, Korsmeyer SJ and Shore GC (1993) Targeting of $\mathrm{Bcl}-2$ to the mitochondrial outer membrane by a $\mathrm{COOH}$-terminal signal sequence. J. Biol. Chem. 268: 25265-25268

9. Goping IS, Gross A, Lavoie JN, Nguyen M, Jemmerson R, Roth K, Korsmeyer SJ and Shore GC (1998) Regulated targeting of Bax to mitochondria. J. Cell Biol. 143: $207-215$

10. Nechestan A, Smith CL, Hsu Y-T and Youle RJ (1999) Conformation of the BAX c-terminus regulates subcellular location and cell death. EMBO J. 18: 23302341

11. Green DR and Reed JC (1998) Mitochondria and apoptosis. Science 281: $1309-1312$
12. Yang J, Siu X, Bhalla K, Kim CN, Ibrado AM, Cai J, Peng T-I, Jones DP and Wang X (1997) Prevention of apoptosis by Bcl-2: release of cytochrome $c$ from mitochondria blocked. Science 275: 1129-1132

13. Kluck RM, Bossy-Wetzel E, Green DR and Newmeyer DD (1997) The release of cytochrome c from mitochondria: a primary site for $\mathrm{Bcl}-2$ regulation of apoptosis. Science 275: 1132-1136

14. LiP, Nijhawan D, Budihardjo I, Srinivasula SM, Ahmad M, Alnemri ES and Wang X (1997) Cytochrome $c$ and dATP-dependent formation of Apaf-1/caspase-9 complex initiates an apoptotic protease cascade. Cell 91: 479-489

15. Scaffidi C, Fulda S, Srinivasan A, Friesen C, Li F, Tomaselli KJ, Debatin K-M, Krammer PH and Peter ME (1998) Two CD95 (APO-1/Fas) signaling pathways. EMBO J. 17: 1675-1687

16. Bossy-Wetzel E and Green DR (1999) Caspases induce cytochrome c release from mitochondria by activating cytosolic factors. J. Biol. Chem. 274: $17484-$ 17490

17. Hsu Y-T, Wolter KG and Youle RJ (1997) Cytosol-to-membrane redistribution of Bax and Bcl-X during apoptosis. Proc. Natl. Acad. Sci. USA 94: 3668-3672

18. Gross A, Jockel J, Wei MC and Korsmeyer SJ (1998) Enforced dimerization of Bax results in its translocation, mitochondrial dysfunction and apoptosis. EMBO J. $17: 3878-3885$

19. Desagher S, Osen-Sand A, Nichols A, Eskes R, Montessuit S, Lauper S, Maundrell K, Antonsson B and Martinou J-C (1999) Bid-induced conformational change of Bax is responsible for mitochondrial cytochrome $c$ release during apoptosis. J. Cell Biol. 144: 891-901

20. Xiang J, Chao DT and Korsmeyer SJ (1996) BAX-induced cell death may not require interleukin $1 \beta$-converting enzyme-like proteases. Proc. Natl. Acad. Sci. USA 93: $14559-14563$

21. Rossé T, Oliver R, Monney L, Roger M, Conus S, Fellay I, Jansen B and Borner C (1998) Bcl-2 prolongs cell survival after Bax-induced release of cytochrome c. Nature 391: 496-499

22. Wang K, Gross A, Waksman G and Korsmeyer SJ (1998) Mutagenesis of the $\mathrm{BH} 3$ domain of Bax identifies residues critical for dimerization and killing. Mol. Cell. Biol. 18: 6083-6089

23. Eskes R, Antonsson B, Osen-Sand A, Montessuit S, Richter C, Sadoul R, Mazzei G, Nichols A and Martinou J-C (1998) Bax-induced cytochrome c release from mitochondria is independent of the permeability transition pore but highly dependent on $\mathrm{Mg}^{2+}$ ions. J. Cell. Biol. 143: 217-224

24. Wang K, Yin X-M, Chao DT, Milliman CL and Korsmeyer SJ (1996) BID: a novel BH3 domain-only death agonist. Genes Dev. 10: 2859-2869

25. Finucane DM, Bossy-WetzelE, Waterhouse NJ, Cotter TG and Green DR (1999) Bax-induced caspase activation and apoptosis via cytochrome $c$ release from mitochondria is inhibitable by Bcl-X $X_{\mathrm{L}}$. J. Biol. Chem. 274: 2225-2233

26. Jürgensmeier JM, Xie Z, Devereaux D, Ellerby L, Bredesen D and Reed JC (1998) Bax directly induces release of cytochrome c from isolated mitochondria. Proc. Natl. Acad. Sci. USA 95: 4997-5002.

27. Kischkel FC, Hellbardt S, Behrmann I, Germer M, Pawlita M, Krammer PH and Peter ME (1995) Cytotoxicity-dependent APO-1 (Fas/CD95)-associated proteins form a death-inducing signaling complex (DISC) with the receptor. EMBO J. 14: $5579-5588$

28. Boldin MP, Goncharov TM, Goltsev YV and Wallach D (1996) Involvement of $\mathrm{MACH}$, a novel MORT1/FADD-interacting protease, in Fas/APO-1- and TNF receptor-induced cell death. Cell 85: 803-815

29. Muzio M, Chinnaiyan AM, Kischkel FC, O'Rourke K, Shevchenko A, Ni J, Scaffid C, Bretz JD, Zhang M, Gentz R, Mann M, Krammer PH, Peter ME and Dixit VM (1996) FLICE, a novel FADD-homologous ICE/CED-3-like protease, is recruited to the CD95 (Fas/APO-1) death-inducing signaling complex. Cell 85: 817-827

30. Medema JP, Scaffidi C, Kischkel FC, Shevchenko A, Mann M, Krammer PH and PeterME (1997) FLICE is activated by association with the CD95 death-inducing signaling complex (DISC). EMBO J. 16: 2794-2804

31. Boise LH and Thompson CB (1997) Bcl-X(L) can inhibit apoptosis in cells that have undergone Fas-induced protease activation. Proc. Natl. Acad. Sci. USA 94: $3759-3764$

32. VarfolomeevEE, Schuchmann M, Luria V, Chiannilkulchai N, Beckmann JS, Mett IL, Rebrikov D, Brodianski VM, Kemper OC, Kollet O, Lapidot T, Soffer D, Sobe T, Avraham KB, Goncharov T, Holtmann H, Lonia P and Wallach D (1998) Targeted disruption of the mouse caspase 8 gene ablates cell death induction by the TNF receptors, Fas/APO-1, and DR3 and is lethal prenatally. Immunity 9: 267-276 
33. Juo P, Kuo CJ, Yuan J and Blenis J (1998) Essential requirements for caspase-8/ FLICE in the initiation of the Fas-induced apoptotic cascade. Curr. Biol. 8: 10011008

34. Scaffidi C, Schmitz I, Zha J, Korsmeyer SJ, Krammer PH and Peter ME (1999) Differential modulation of apoptosis sensitivity in CD95 type I and type II cells. J. Biol. Chem. 274: 22532-22538

35. Fujiki Y, Fowler S, Shio H, Hubbard AL and Lazarow P (1982) Polypeptide and phospholipid composition of the membrane of rat liver peroxisomes: comparison with endoplasmic reticulum and mitochondrial membranes. J. CellBiol. 93:103110

36. McBride HM, Goping IS and Shore GC (1996) The human mitochondrial import receptor, hTom20p, prevents a cryptic matrix targeting sequence from gaining access to the protein translocation machinery. J. Cell Biol. 134: 307-313

37. Liu X, Kim CN, Yang J, Jemmerson R and Wang X (1996) Induction of apoptotic program in cell-free extracts: requirement for dATP and cytochrome c. Cell 86 : $147-157$

38. Yin X-M, Wang K, Gross A, Zhao Y, Zinlle S, KlockeB, Roth KA and Korsmeyer SJ (1999) Bid-deficient mice are resistant to Fas-induced hepatocellular apoptosis. Nature 400: 886-891

39. Khaled AR, Kim K, Hofmeister R, Muegge K and Durum SK (1999) Withdrawal of IL-7 induces Bax translocation from cytosol to mitochondria through a rise in intracellular pH. Proc. Natl. Acad. Sci. USA 96: 14476-14481
40. Nouraini S, Six E, Matsuyama S, Krajewski S and Reed JC (2000) The putative pore-forming domain of Bax regulates mitochondrial localization and interaction with Bcl-X. Mol. Cell. Biol. 20: 1604-1615

41. Eskes R, Desagher S, Antonsson B and Martinou J-C (2000) Bid induces the oligomerization and insertion of Bax into the outer mitochondrial membrane. Mol. Cell. Biol. 20: 929-935

42. Schendel SL, Azimov R, Pawlowski K, Godzig A, Kagan BL and Reed JC (1999) Ion channel activity of the BH3 only Bcl-2 family member, BID. J. Biol. Chem. 274: 21932-21936

43. Xu Q and Reed JC (1998) Bax inhibitor-1, a mammalian apoptosis suppressor identified by functional screening in yeast. Mol. Cell 1: 337-346

44. Boulakia CA, Chen G, Ng FWH, Teodoro JG, Branton PE, Nicholson DW, Poirier GG and Shore GC (1996) Bcl-2 and adenovirus E1B $19 \mathrm{kDa}$ protein preventE1Ainduced processing of CPP32 and cleavage of Poly(ADP-ribose) polymerase. Oncogene 12: $529-535$

45. Ng FWH, Nguyen M, Kwan T, Branton PE, Nicholson DW, Cromlish JA and Shore GC (1997) p28 Bap31, a Bcl-2/Bcl- $X_{L}$-and procaspase-8-associated protein in the endoplasmic reticulum. J. Cell. Biol. 139: $327-338$

46. Nguyen M, Branton PE, Roy S, Nicholson DW, Alnemri ES, Yeh W-C, Mak TW and Shore GC (1998) E1A-induced processing of procaspase-8 can occur independently of FADD and is inhibited by Bcl-2. J. Biol. Chem. 273: 3309933102 